\title{
Supporting factors in the aqidah-akhlaq teaching and learning process (study at islamic senior high schools in West-South Aceh regions)
}

\author{
Fedry Saputra \\ Sekolah Tinggi Agama Islam Negeri (STAIN) Teungku Dirundeng Meulaboh \\ Email : fedrysaputra@yahoo.co.id
}

DOI: $10.18326 /$ attarbiyah.v4i2.229-249

\begin{abstract}
The subject of aqidah-akhlaq has a contribution in providing motivation to students to practice the values of religious belief (monotheism) and moral behavior in daily life. In this study, supporting factors in the implementation of the learning process of this subject at Islamic senior high schools (MAs) were the factors of the teachers and the environment. The research is concerned with, firstly the delivery of the teaching and learning process on the aqidahakhlaq subject at MAs, and secondly the supporting factors of teachers in the learning process of the aqidah-akhlaq subject in MA students. This research used a qualitative approach with descriptive research method. Meanwhile, the data was collected through observation, interviews, and documentation. Research subjects were MA teachers who were in the West-South Aceh covering 5 regions: Aceh Jaya, West Aceh, Nagan Raya, Southwest Aceh, and South Aceh. The results showed that (1) there were several steps in the learning process carried out by the teachers, i.e. preparing lesson plans, delivering subject consisting of two aspects: firstly varied teaching methods and secondly varied learning media, conducting an assessment of learning outcomes, and performing follow-up efforts through individual approaches to deal with problematic students, and (2) in terms of supporting factors from both parents and society, it showed that some were supportive and some others did not care of their children.
\end{abstract}

Keywords: learning, aqidah-akhlaq, MA (Islamic senior high school), West South Aceh 
Attarbiyah: Journal of Islamic Culture and Education

https://www.attarbiyah.iainsalatiga.ac.id/index.php/attarbiyah/

\section{INTRODUCTION}

Education is a teaching-learning process that can result in expected behavior change. In Islamic education, the construction of moral values is the main goal of education itself. This is in line with the purpose of the Messenger of Allah being in this world, which is to improve human morals, as stated in a hadith: From Abu Hurairah, he said: The Prophet (peace be upon him) said: "I am sent (by Allah) to fulfill the highest good ( morals) ". (HR. Baihaqi).

Behavior formation is an ongoing activity in everyday life. It is expected that students will be able to develop good habits that can be reached through the formation of religious morals, feelings/emotions, social skills, and discipline. The competence from the cultivation of moral values to be achieved in the aspect of moral development and religious values is the ability to worship, to know and believe in God's creation, and to love one another. Akhlaq has a great effect on individuals and on a nation. In a poem it is said: "Surely a nation shall live forever as long as the people value the morals, if their morals are destroyed they will be destroyed" (Baradza, 1992).

The purpose of Islamic education is to drive Muslims in total devotion to Allah, both individually and communally and as a whole. To achieve this goal, the madrasah (school) as a religious education institution makes aqidahakhlaq subject as the foundation for the development of the students' spiritual values. Education itself is a very urgent matter and not an amateur job, but a professional occupation that cannot be passed on just to anyone.

The factors that influence whether or not moral education is implemented in educational institutions i.e. schools, especially in MA, are as follows: The first factor is the problem of teachers' teaching quality having educational background or teacher training, which in turn determines the 
level of educational success, including the aqidah-akhlaq education. Considered heavily important, aqidah-akhlaq education is not merely about conceptual maturation; more than that it must entail a mature behavior as a mirror of the morals that are owned after learning aqidah-akhlaq itself. This problem also includes the use of methods in educating and teaching that are efficient and time-efficient. The second factor is students; in education, their existence cannot be ignored. Likewise in the field of aqidah-akhlaq education, the presence of students with varying levels of participation will determine the success of education itself. If it happens that the students' participation level is below the standard/low, then chances are the teaching would be difficult to proceed. In turn, it will lead to failure. In contrast, if the students participate well then the opportunity to achieve the success of moral education is widely open. The third factor is infrastructures and facilities; in educational conception, their availability is very crucial to support educational success. Their availability and maximum utilization in aqidah-akhlaq learning are very helpful to reach its success. The more complete infrastructures and facilities are, the bigger the chance presents to contribute to the learning success. On the contrary, the more limited they are (also misutilization), moral education is likely to be failed or hampered. The fourth factor is environment; moral learning success is largely influenced by the surrounding environment. If it is able to reflect a positive activity for the moral learning process, then it is likely to make a good contribution to the implementation of education. However, if the environmental conditions are proven to be irrelevant to the moral learning process, it will clearly yield a less maximal moral education process itself (Nata, 2011). 
Those are some of the factors that are quite influential in how aqidahakhlaq learning is applied, and contribute to its success and failure, in the sense that these factors will affect the success level of implementation of aqidah-akhlaq leaning in educational institutions. In line with that, to be a nobleman, a process of personality formation should be done, which cannot grow suddenly and immediately. In its process, a range of strategies, discourse, and the right method are highly required.

However, the practice of moral education in schools has not shown encouraging results. Various events lately, especially after Aceh hit by various crises, earthquakes, and tsunami, many strange things have happened among some children. Various phenomena that reflect on the attitudes that are not based on noble morals have reached our nation's children. The social reality developing in the midst of society goes around the emergence and increasingly widespread moral decadence of society including among students. The occurrences of students brawls, the increasing involvement of adolescents in the use of drugs, arson, violence, murder, pillaging, rape, corruption, and other violence against the law are the indication of moral decline.

The impact of such a moral degradation can be seen in almost all aspects of the behavior of MA students, ranging from social clothing, hairstyles, and the use of communication tools for negative things. When they come home from school, students dare to travel without wearing their hijab, without the slightest feeling of discomfort. There are also many male students who have been influenced by impolite behaviors. In terms of relationship, it looks as if there is no more limitation between boys and girls. They dare to sit on the train together like a couple who has done the marriage consent, 
coupled with the number of students who do not do the prayers and other forms of worship.

The factor which is very supportive in the implementation of the aqidah-akhlaq learning process at MA is teachers. They are very instrumental in carrying out the task of educating student behavior. The problem is that the teachers there could not be a model for students in implementing morals at the school. Therefore, students' understanding of the importance of moral education is still lacking. This is a task for teachers of the aqidah-akhlaq subject in increasing students' understanding. Many teachers only teach theories, while their application in daily life is still lacking.

In principle, various behaviors of MA students in West South Aceh regions today do not meet the criteria for morals according to the desired teachings of Islam. From the above problems, the writer is interested in conducting a study as outlined with the theme: Supporting Factors in the teaching and learning process of Aqidah-Akhlaq Subject for MA Students in West South Aceh Regions.

From the background of the problem above, there were several issues that could be identified, including:

1. how the teaching and learning process on the aqidah-akhlaq subject at MA was.

2. what the supporting factors of the teachers in the learning process of the aqidah-akhlaq subject in MA students were.

\section{Theoretical basis}

In terms of its linguistic origin, aqidah derives from Arabic "AqadaYa'qidu'uqudatan", which means a bond or agreement, i.e. something to which the heart and conscience to be bound (A.Zainuddin, 1999). While according 
to the terminology, Aqidah is a core or fundamental belief that must be held by an individual. Islamic Aqidah is the basis of teachings that purify (bind) devotion to Allah, never serve any other than Allah.

"Akhlaq (moral)", etymologically taken from Arabic in the plural form. Al-Khulq is a mufrod (singular) form of Akhlaq which means habit, temperament, and characteristics. It is a behavior that has become a habit and appears intentionally, the word akhlaq in this sense is mentioned in the Qur'an in the singular form, while the word khulq in the word of Allah SWT is a gift to Muhammad as a form of appointment to be the Apostle of Allah. (Abdullah M. Yatim, 2005)

The basis of aqidah is the teachings of Islam itself which are sources of law in Islam, i.e. Qur'an and Al-Hadith. They are guidelines for life in Islam that explains the criteria or measure of the merits of a human being. The first and foremost basis of aqidah-akhlaq is Qur'an. When asked about the aqidahakhlaq of the Prophet Muhammad SAW, Siti Aisyah said, "The basis of aqidah-akhlaq of the Prophet Muhammad SAW is Qur'an."

Islam teaches people to do good deeds and to avoid bad ones. These good and bad measurements are said in Qur'an. Because Qur'an is the word of God, from which the truth must be believed by every Muslim.

In Surah Al-Maidah verses 15-16 aqidah-akhlaq must be a guide for every Muslim. This means that every Muslim must believe in the main essences of such aqidah-akhlaq. The objectives of it are:
a) to cultivate and develop the divine basis from birth.
b) to form a noble Muslim.
c) to avoid the influence of misleading thoughts. 
As for the learning and teaching process, many things must be considered by teachers of this subject. An ability to deliver a lecture with the help of a piece of chalk is not enough to successfully carry out the learning of aqidah-akhlaq. It turns out that far from it, there are still many other problems that determine the success of this aqidah-akhlaq learning process. Therefore, the researcher asserts the following description as a minimal condition for reaching the goal:

1) Programmed Lesson Plan

A religious teacher should carefully pay attention to the lesson plan before teaching aqidah-akhlaq. This means that when performing a teaching and learning process there must first be a well-planned lesson plan. This is useful to manage the material that will be delivered and to avoid the irregular delivery of material. Because aqidah-akhlaq education must be taught systematically in accordance with the order of the material organization and existing levels of education.

2) Material Delivery of the Subject

After an instructional program through the planning is established, then the next step is an effort to deliver the material.

a. Learning method. After an instructional program through the planning is established, then the next step is an effort to deliver the material.

b. Instructional Media. There are so many types of instructional media. To use a better, more effective and efficient learning media, it requires the ability, and knowledge in choosing, and using them. 
3) Conducting Assessment of Aqidah-Akhlaq Learning Outcomes

After a religious teacher presents the material through an impressing delivery which reflects a model for the true faith and noble character, then it is expected that he is able to capture the results of education and teaching in each student. This surely has to go through a quite long process in that assessing the success level of a student could not be done in a blink of an eye; instead, it requires a range of processes and parts assessed.

Further, the assessment must be programmed precisely, local content must be able to reflect the part of the assessment to be evaluated, which refers to formative, subsummative, and summative assessment. Likewise, the final assessment must be planned carefully. So that student learning outcomes will be obtained objectively.

4) Follow-Up Efforts / Approach

After evaluating students' learning outcomes, then the Islamic religion teachers in the subject of aqidah-akhlaq should plan a follow-up effort to the existing results. This is important in order to follow up on progress/failure performed by students in that it aims at improving their weaknesses. On the other hand, this follow-up effort also serves to see the performance of the teachers, whether they are able to become a professional educator or not, because the results of children depend on their existence.

Amidst many factors influencing the morals of students, perhaps this is not an easy matter. Because, the emphasis is not on the place where the teaching takes place, nor on the students themselves, but there are several aspects taking a part in affecting students' moral performance, including: 
1) Familial factors; consisting of social and economic conditions of the family, and parents' attention,

2) Environmental factors; society plays an important role in the formation of children's morals. Theoretically, the community's environment also influences children's attitudes and behavior on the extent of their socialization and interaction with the community and the surrounding environment. (A. Setyawan, 2003)

\section{METHODS}

This research was conducted using descriptive method with a qualitative approach. The study was conducted with a predetermined sample of teachers who taught aqidah-akhlaq subject at targetted MAs (public and private). The research procedure was carried out through the stages of planning, determining the focus of research, managing the time of research, collecting and analyzing data, and presenting research results - which was done descriptively through qualitative work steps. In this case, it is called qualitative because the nature of the data collected was qualitative, that is, it does not use measuring devices. The qualitative method produces descriptive data, both in the form of written and oral expressions of observed people and behavior. (Lexi J Moleong, 2002)

While the participants interviewed in this study were teachers teaching aqidah-akhlaq at MAs (both public and private) within the scope of the Ministry of Religion in the five Regencies in West South Aceh or which was predetermined. In addition, the participants were also selected using purposive sampling technique because the researcher's certain considerations in taking the sample became the concern (Ridwan, 2011). 
The method of data collection is highly dependent on the kind of problem, the type of research, and the situation of the research. For this reason, in this study, the data collection techniques used were:

1. Observation, a complex data collection technique that is composed of various biological and psychological processes.

2. Interview, to obtain information directly from the source. The researcher conducted direct interviews with teachers teaching aqidah-akhlaq who graduated from Islamic religious education major or who were intentionally recruited to teach aqidah-akhlaq at public or private Mas in West South Aceh.

3. Documentation, a complement to the use of observation and interview techniques. The results of interview and observation will be more credible supported by the availability of concrete evidence, whether in the form of writing, living drawings, or one's monumental works.

\section{DISCUSSION}

\section{West-South Aceh Demographics}

The study was conducted on Islamic education teachers both graduates of Islamic Religious Education and general teachers who were given a decree (SK) to teach aqidah-akhlaq subject in public or private MAs in West South Aceh. The sampling was carried out in several research locations that had been determined in a cluster or region, i.e. in the districts of Aceh Jaya, West Aceh, Nagan Raya, Southwest Aceh, and South Aceh. There were 2,4, and 5 madrasas in each region or district selected. The selection of madrasas with this type of cluster was chosen after the budget and time availability were 
considered. In addition, the data found should be representative to draw the desired research conclusion.

Overall, data on the teachers of aqidah-akhlaq subject interviewed can be seen through the following table.

Table 01: Names of madrasas and PAI teachers interviewed at the study site

\begin{tabular}{|c|c|c|c|}
\hline No & Regency / City & Madrasa Name & $\begin{array}{l}\text { Respondents/Aqidah- } \\
\text { Akhlaq Teachers' Name }\end{array}$ \\
\hline \multirow{4}{*}{\multicolumn{2}{|c|}{ West Aceh }} & MAS Meurebo & Samsinarwati. S.Pd.I \\
\hline & & MAN 3 West Aceh & Samsuardi. S.Pd \\
\hline & & MAN 1 West Aceh & Cut Ima Samsidari. S.Pd.I \\
\hline & & MAN 2 West Aceh & Mukhtasanah, S.Ag \\
\hline \multirow{2}{*}{\multicolumn{2}{|c|}{ Nagan Raya }} & MAN 1 Nagan Raya & Suarni \\
\hline & & MAS Darul Makmur & Muhammad Nur. S.Pd.I \\
\hline \multirow{6}{*}{\multicolumn{2}{|c|}{ Aceh Jaya }} & \multirow{3}{*}{ MAN 1 Aceh Jaya } & Siti Saharah. S.Pd.I \\
\hline & & & Syafruddin Umri. S.Ag \\
\hline & & & Aiyusliadi, MZ.S.Ag \\
\hline & & MAS Calang & Putri \\
\hline & & MAS Ar-Risalah & Julia Deni \\
\hline & & MAS Patek & Subhi. S.Pd.I \\
\hline \multirow{3}{*}{\multicolumn{2}{|c|}{ Southwest Aceh }} & $\begin{array}{l}\text { MAN } 1 \text { Southwest } \\
\text { Aceh }\end{array}$ & Erni Tri Juliati. S.Ag \\
\hline & & \multirow[b]{2}{*}{ MAS Kuala Batee } & $\begin{array}{l}\text { Syahrul Ramadhan, } \\
\text { S.Pd.I }\end{array}$ \\
\hline & & & $\begin{array}{l}\text { Raihan Rahmi Chaidir, } \\
\text { S.Pd.I }\end{array}$ \\
\hline \multirow{3}{*}{\multicolumn{2}{|c|}{ South Aceh }} & MAN 1 South Aceh & Iswali. S.Pd.I \\
\hline & & $\begin{array}{l}\text { MAS Jabal Rahmah } \\
\text { Tapaktuan }\end{array}$ & Rayon Rahmah. \\
\hline & & $\begin{array}{l}\text { MAS Labuhanhaji } \\
\text { Timur }\end{array}$ & Ali. S.Pd.I \\
\hline
\end{tabular}




\begin{tabular}{ll} 
MAS Labohanhaji & Mardhannah. S.Ag \\
Barat & \\
\hline $\begin{array}{l}\text { MAS Al-Munjiya } \\
\text { Labohanhaji Barat }\end{array}$ & Yunus \\
\end{tabular}

Teaching and Learning Process in Aqidah-Akhlaq Subject

1) Aqidah-Akhlaq Lesson Plan

Planning is the initial action to carry out learning. It determines the goal and appropriate method to achieve learning objectives. A lesson plan is essentially the design of efforts to teach students. Learning focuses on how to enable students to learn, and not on what students learn. Generally, lesson plan is required to help achieve learning improvement. It is supported by the results of interview with the aqidah-akhlaq teachers that before starting the teaching they prepared a lesson plan in advance (MAS Laboh Haji Barat).

Teachers are similarly on a strategic, important and major position in supporting national development, especially in building the quality of human resources. Their role is the agent of knowledge, skills and technology delivery to students, who are national assets. The quality of human resources will be improved since teachers are not merely to transfer knowledge to the students. They are a professional who makes students able to understand, plan, analyze, and conclude the problems faced. The existence of teachers who work professionally will make students experience maturity in ways of thinking, action, and personality. Therefore, teachers need to have a broad insight, high ideals, strong personality, and humanity. In addition to preparing lesson plans, the respondents mentioned that they should be able to control classroom 
conditions before apperception was conducted that later followed by the introduction of new material. After all, it should also be supported by the ability to teach good ethics. (MAN 1 Aceh Jaya, MAS Calang Aceh Jaya, MAS Kuala Batee Abdiya)

2) Material Delivery of Aqidah-Akhlaq Subject

a. Teaching and Learning Method in Aqidah-Akhlaq Subject

The application of the right method greatly influences the success of teaching and learning. Likewise, mistakes in choosing teaching method will be fatal. Most of the Aqidah-Akhlaq teachers at Madrasah Aliyah who were interviewed by the researcher stated that in the learning process, they tried to carry out learning so that students paid attention and learning objectives could be achieved. Yet such a lecture method was more dominantly used that it resulted in the lack of students' involvement in the learning activity. They tended to prefer to chat with their classmates or sleep in the class when the teacher explained the subject matter. Other problems like materials which were not interested for students, the lesson hours during the daylight yielding in tiredness, and less varied teaching methods made the teaching and learning become ineffective (MAN 3 West Aceh, MAS Almunjiya South Aceh, MAS Calang Aceh Jaya, MAN 2 West Aceh, MAN 1 West Aceh, MAS Jabal Rahmah South Aceh, MAS Labohanhaji Barat South Aceh, MAS Labohanhaji Timur South Aceh, MAS Meureubo South Aceh).

The teaching and learning process should be designed to be fun for students and teachers. When students are happy, they will be engaged in the learning process well by responding to teachers' 
explanations, for instance. However, such matters still received lack attention from the teachers except for a teacher from MAN I Aceh Jaya who preferred game technique so that the students were not sleepy during the class which proceeded in the last-hour session. Using the new way of reaching learning objectives with the support of various methods through discussion, group work, and presentation, the teacher ended the activity by making an evaluation through interview.

b. Instructional Media in the Teaching and Learning Process of AqidahAkhlaq Subject

To be able to achieve learning objectives, teachers should not only master the material but also the techniques for its delivery so that learning becomes more effective. Teachers are expected to have the ability in selecting and using appropriate method, which is a teaching tool, to succeed in educational practice.

One of the methods applied in the schools observed was socio-drama. Based on the interview and observation results, the steps of this method which was conducted by the teachers were as follows:

a) The teacher explained the socio-drama method in a simple way to a group of students who newly dealt with it.

b) The situation of the problem to be played was set in such a way that it attracted the students' attention.

c) The teacher told the event sufficiently to arrange the scene or provide mental readiness for the students.

d) If the socio-drama was done for the first time, the teacher would choose the students himself to play the role. 
e) The teacher set other students as listeners (those who did not participate in carrying out the task).

f) The teacher clearly explained the problem and the role they must play.

g) The teacher suggested a good first sentence spoken by the player to begin.

h) The teacher stopped the socio-drama at the moment the situation was reaching the peak and then opened a general discussion.

i) In the discussion, students would sometimes be asked to solve the problem in other ways.

j) Teachers and students drew conclusions. (MAN 1 Aceh Jaya)

The media that was often used by teachers in some MAs was books.

They are one of the most effective learning media in the teaching and learning process, especially in aqidah-akhlaq.

1. Conducting Assessment of Aqidah-Akhlaq Learning Outcomes

Aqidah-akhlaq learning outcomes in the learning process are one of the components towards desired behavior change to measure student learning output. It is an ability expected to be possessed by students after going through a learning experience, both in the form of affective and psychomotor aspects. These changes in human behavior can be known through perception, which means experience generated through the sense of sight, hearing, and so on. In this case, everyone has a different perception, even though the object is the same. Besides, someone performing good or bad behavior is based on the principle of motivation. In other words, motivation - the urge to act to achieve certain goals drives students to do either good or bad behavior. 
Derived from the results of interviews with the teachers, it showed that in the process of student evaluation, they made careful preparations, not only in terms of the objectives to be achieved, but also in the aspects to be assessed, and the methods as well as tools for evaluation. At the end of session, a post-test was often conducted because it was very important to know the extent to which students understood and absorbed the material conveyed. There were actually three components to be considered in composing the test i.e. cognitive, affective, and psychomotor aspects. In addition, the way that was done to select the material was through making sense of the material well, interpreting it, or concerning which aspects entailed in the material. This was because a material could sometimes contain two or even three aspects at once (interview with the teachers of MAN 3 West Aceh, MAS Labohanhaji Barat, MAS Ar-Risalah Aceh Jaya, MAS Meureboh West Aceh, MAN 2 West Aceh, MAN 1 West Aceh, MAN 1 Nagan Raya, MAS Jabal Rahmah South Aceh, MAS Al-Munjiya, MAS Labohanhaji Timur, South Aceh, MAN 1 Abdiya, MAN 1 Aceh Jaya, MAS Calang Aceh Jaya, and MAS Kuala Batee Abdiya).

2) Follow-Up Efforts / Approaches to Foster Students' Morals

Basically, the behavior of students can be improved well through the establishment of discipline made by the principal to be applied at school by all school members ranging from teachers to the students themselves. If students violate the rules of school discipline from which they will be given some points that have been determined, they will, in turn, be fostered through advice, or agreements making with which parents also present there. Further, if they mad another violation, additional points will be given according to the type of its violation. "Then, once, there was a 
student who was late coming to school. When asked if he performed the subuh prayer, he said no. On the second day, he was asked the same question and he said yes. On that day onwards he has never got late." (MAN 1 Aceh Selatan)

From an interview with teachers on how to deal with their students, they shook hands and gave more advice just like educating elementary school or preschool children, by giving many praises. Outside the study hours, extra-curricular activities were held to support Islamic education learning - which is only ninety minutes - in an effort to develop students' morals such as: Muhadharah, recitation of Qur'an every Saturday (MAS Kuala Bate). Every day from Monday to Thursday, students were encouraged to perform Dzuhur prayers at the school mosque. After completing prayer in congregation, students carried out tausiyah (preaching) about akhlaq. The results of the extra-curricular activities would later be handed to the homeroom teacher to be inputted in the Report Card in the column of extra-curricular activities signifying students' participation in the fields of Religion, Sports, Arts, Scouts and so on "

Supporting factors from the teacher aspect in the teaching-learning process of aqidah-akhlaq subject

\section{1) Parental Support Factor}

Environment is a place where a child grows and develops and plays an important role in shaping one's personality and character. For most children, family is the early environment that affects their development, which is then followed by school and community environment. It is built by parents and closest people. Each family has differences in many ways, including how to educate the children and economic status. It has its own history, values, and 
habits that run in all family members and unconsciously shape children's characters.

Referring to the interview results in all schools, parents were very instrumental in the formation of children's morals. There were some parents who keenly cared for their children's studying routines. However, there were also some other parents who were more concerned with making money rather than paying attention to their children's education. Sometimes they went for work leaving their children home and would be back after a month.

2) Community Support Factor

The findings from the interview showed that there was a lack of support provided by the surrounding community. Whereas, it is highly crucial to succeed an education (MAN 3 Patek West Aceh, MAN 2 West Aceh, MAS Calang Aceh Jaya, MAS Kuala Batee Southwest Aceh and MAS Labohanhaji Timur South Aceh)

Further, many people in society, especially teenagers, were unemployed; they did not have any job nor work on their education. As a result of unemployment, they were left behind in many aspects of life: education, economy, and so on.

Under these circumstances, teenagers acted stupidly in behaving, mingling, and in everything experienced in their lives. They were likely to do their own rules of life, even though they were in contrast to the teachings of Islam and customs in the local area.

Controversial rules of life conducted by teenagers did not stop there. They tended to speak disrespectfully, smoke marijuana openly in public, sit at the roadside when the maghrib (red: evening, time to perform a prayer) came. 
Such behaviors can dangerously affect the children because their nature is to imitate.

When children are out of the house, they are immediately faced with a broad environment. If it is not good, then children in the area are unlikely good. It is likely that they may firstly see, then try, and finally be addicted to bad deeds. Bad attitude committed by teenagers can be bad for children's behavior, such as fading religious norms in children. Hence, efforts should be made so as not to affect the attitude of children.

\section{CONCLUSION}

Based on the description in the previous discussion and the study made by the researcher at MAs in West-South Aceh Regions, the conclusion was drawn as follows:

1. The teaching and learning process implemented by aqidah-akhlaq teachers at MAs in West-South Aceh Regions included:

a. Planning, as the initial action to carry out learning which helped determine the goals and establish appropriate methods to achieve learning objectives. Planning was often done by the teachers by making learning tools.

b. Material delivery of aqidah-akhlaq subject, which consisted of firstly the use of the right methods to help succeed material delivery, and secondly the use of instructional media which played an important role in the teaching and learning process i.e. to assist in reaching learning objectives set in the curriculum.

c. Conducting assessment of aqidah-akhlaq learning outcomes by considering three aspects in composing the test questions, namely 
cognitive, affective, and psychomotor elements. The way being done to select the material was through making sense of it well, interpreting it, or concerning which aspects entailed in it.

d. Follow-up efforts using individual approach, through which the teaching and learning activities focused on assistance and tutorial for each individual. During the learning process, the teachers would definitely find problems related to learners' differences.

2. Factors affecting student morals included:

a. Environmental factors; a place where a child grows and develops. It plays an important role in shaping one's personality and character. For most children, family is the early environment that affects their development, which is then followed by school and community environment. It is built by parents and closest people. There were some parents who keenly cared for their children's studying routines. However, there were also some others who were more concerned with making money rather than paying attention to their children's education.

b. Familial factors, including firstly the parents' education level that becomes a very crucial issue in a group or society, because the progress of a society depends very much on its people's education level; secondly economic level, at which those who have higher education are likely to have high economic level. This is based on the underlying evident where people with high education are easer to find a job. In other words, education and economy are interrelated. The study found that there were some people who supported education but there were also some others who were less concern about it. 


\section{REFERENCES}

Al-Baihaqi. Sunan Kubra. Jilid X. Beirut: Darul Fikri. Tt

Asmaran. (1999). Pengantar Studi Akhlak. Jakarta: Lembaga Studi Islam dan Kemasyarakat

Baradza, U. (1992). Bimbingan Akhlak Bagi Putra-putri Anda, Surabaya: Pustaka Progressif

Nata, A. (2011). Perspektif Islam Tentang Strategi Pembelajaran. Jakarta: Kencana

Moleong, L.J, (2002). Metodologi Penelitian Kualitatif. Bandung: Remaja Rosdakarya

Mujiono, I. 'et.Al'. (1998). Ibadah dan Akhlak dalam Islam. Yogyakarta: UII PressIndonesia

Riduwan. (2011). Belajar Mudah Penelitian Untuk Guru Karyawan dan Peneliti Pemula, Cet. Ke-7, Bandung: Al-Fabeta

Setyawan, A. (2003). Deagamisasi Keluarga. Jurnal Basis. No. 05-06. Tahun Ke52. Mei-Juni. Yogyakarta: Yayasan Basis

Sugiyono. (2008). Metode Penelitian Kuantitatif Kualitatif dan REDD. Bandung: Alfabeta

Sukardi. (2009). Metode Penelitian Pendidikan, Kompetensi dan Praktiknya. Cet. Ke-7. Jakarta: Bumi Aksara

Yatim, Abdullah M. (2005) Studi Akhlak dalam Perspektif Al Qur'an. Jakarta: Amzah

Zainuddin, A. (1999). Al-Islam Aqidah dan Ibadah, Jakarta: Pustaka Setia 